\author{
ONDŘEJ ŠERÝ \\ Masaryk University, Brno, Czech Republic \\ VÁCLAV TOUŠEK \\ Palacký University in Olomouc, Czech Republic
}

\title{
Evaluation of Changes in the Branch and Educational Structure of the Labour Force in the Czech Republic with an Emphasis on Manufacturing and Services ${ }^{1}$
}

\begin{abstract}
This paper deals with the evaluation of changes in the labour force in the Czech Republic after 1989 and focuses on the branch and educational structure. The changes are also compared with processes in other countries of Central Europe.

In the late 1980s the employment rate by sectors of the economy was different in Central European countries when compared with the situation in Western countries. Even subsequent transformation did not change the high share of industry and construction in total employment in the Czech Republic and Slovakia or a lower share of services. Within the manufacturing industry two stages can be distinguished. In the nineties, the majority of branches experienced a decrease in employment, whereas in the first decade of the $21^{\text {st }}$ century stagnation or even reindustrialization occurred, especially when the branches associated with the automotive industry grew (other branches continued to decline). At the regional level, a diversification process was taking place all the time, if you like the transition from the specialization to the diversification.

The importance of education is constantly increasing and the number of people with secondary education with GCE and tertiary education is growing. The relationship between the unemployment rate in districts of the Czech Republic and the share of employed people with tertiary education intensifies. The tertiary sector shows the highest level of education (in some branches of services more than onethird of employed has a tertiary education).
\end{abstract}

Key words: labour force, branch structure, educational structure, transformation, Czech Republic

\section{INTRODUCTION}

Economic geographers in Central and Eastern Europe have recently focused their studies on space- and sector-related changes brought about by the transformation process experienced

${ }^{1}$ This paper has been written as part of the OP EC "Innovation of teaching geographical subjects" (Geoinovace), funded by the European Social Fund and the state budget of the Czech Republic (reg. no.: CZ.1.07/2.2.00/15.0222). The team members include the Department of Geography at the Faculty of Science of Masaryk University in Brno and the Department of Geography at the Faculty of Science, Palacký University in Olomouc. 
by the national economies since the beginning of the 1990s. These changes were strongly affected by the European integration and the process of globalisation taking place in the global economy. Regardless of changes entailed by the global economic crisis, recent changes in national economies have been affected most by the foreign capital inflow. Its role is evaluated in a number of geographical studies. In the Czech Republic, this topic is covered primarily by Pavlínek (2004), Kunc (2005), Vančura (2006), Fišer, Toušek and Janota (2008), Ženka (2008, 2009) and Šerý (2012); in Poland, by Stryjakiewicz (2009), Domański (2011), Gierańczyk and Rachwał (2012); in Hungary, by Barta (2005) and Barta, Czirfusz and Kukely (2008); and in Slovakia, by Kulla (2005), Popjaková (2008) etc.

The objective of this paper is to evaluate the sector-related changes in the Czech Republic at the time of the market economy and to focus in a greater level of detail on analysing the changes in the educational structure of the Czech labour force. The evaluation also makes use of the preliminary and final results of the 2011 census. Changes in the Czech Republic are compared against changes taking place in the other V4 countries (Czech Republic, Hungary, Poland and Slovakia) and the EU countries.

\section{Changes IN THE BRANCH STRUCTURE OF EMPLOYED}

At the end of the 1980s, the sector-related employment structure in former Czechoslovakia strongly differed from the other transition economies in Central Europe. The sectors of agriculture, forestry and fishing employed less than $12 \%$ employees, which was, on the one hand, more than in the developed market economies, but substantially less than in neighbouring Hungary (19.8\%) and, in particular, Poland (25.5\%). On the other hand, industry and construction employed almost half labour force in Czechoslovakia (45.3\%), i.e. most of all European countries. In terms of employment, in Poland and Hungary the share of the secondary sector of economy did not even reach the level of $40 \%$ of the total employment. The tertiary sector was the largest employer at that time only in Hungary (43.0\%); nevertheless, Czechoslovakia recorded a slightly higher share in total employment (43.4\%). Both of these values are a long way behind the values reported by the countries in Western Europe (Belgium $69.2 \%$, Norway $68.7 \%$, France $64.0 \%$ etc.). At the end of 1989 , only $36.2 \%$ of people were employed in the tertiary sector in Poland.

The 1990s represented a period of major structural changes in employment in European countries. The most significant movements occurred in the former socialists countries that set out towards a market economy. Major decrements in the number of employees were reported in both the production sectors of economy. The results of the selective labour force survey conducted in 2001 indicate that the share of people employed in agriculture, forestry and fisheries totalled $18.0 \%$ in Poland, $6.2 \%$ in Hungary and Slovakia and $4.9 \%$ in the Czech Republic. Ten years later, the aforesaid countries reported lower values, i.e. $12.2 \%$ in Poland, $4.8 \%$ in Hungary, $3.1 \%$ in Slovakia and $3.0 \%$ in the Czech Republic.

The Czech Republic, similarly to Czechoslovakia prior to its break-up at the end of 1992 , is still a country with the highest share of people employed in industry and construction 
not only in the European Union, but in entire Europe, although the share has been slightly decreasing (see Tab. 1). The secondary sector has a significant share in the employment rate also with respect to other transforming countries in Central Europe.

Tab. 1. Employment in industry and construction in the EU-27 countries

(\% of the total employment rate)

\begin{tabular}{|c|c|c|c|c|c|}
\hline \multicolumn{3}{|c|}{ Year 2001} & \multicolumn{3}{|c|}{ Year 2011} \\
\hline No. & Country & $\%$ & No. & Country & $\%$ \\
\hline 1 & Czech Republic & 40.7 & 1 & Czech Republic & 38.6 \\
\hline 2 & Slovenia & 39.6 & 2 & Slovakia & 37.5 \\
\hline 3 & Slovakia & 37.1 & 3 & Estonia & 32.5 \\
\hline$\cdot$ & & & . & & \\
\hline 6 & Hungary & 34.5 & 6 & Poland & 30.9 \\
\hline$\cdot$ & & & 7 & Hungary & 30.9 \\
\hline 11 & Poland & 31.3 & $\cdot$ & & \\
\hline$\cdot$ & & & . & & \\
\hline 25 & Greece & 23.4 & 25 & Greece & 18.0 \\
\hline 26 & Netherlands & 21.7 & 26 & Netherlands & 17.2 \\
\hline 27 & Luxembourg & 21.5 & 27 & Luxembourg & 13.2 \\
\hline & EU-27 & 29.5 & & EU-27 & 25.4 \\
\hline
\end{tabular}

Source: EUROSTAT (2012): Labour Force Survey - Employment and Unemployment

Tab. 2. Labour force in manufacturing industry at the end of 1989 and 1999

\begin{tabular}{|l|r|r|r|r|}
\hline \multicolumn{1}{|c|}{ Branch of manufacturing industry } & 1989 & 1999 & $\begin{array}{c}\text { difference } \\
1999-1989\end{array}$ & $\begin{array}{c}\text { change index } \\
1999 / 1989 * 100\end{array}$ \\
\hline food-processing & 144,959 & 146,551 & 1,592 & 101.1 \\
\hline textile & 155,423 & 72,575 & $-82,848$ & 46.7 \\
\hline clothing & 55,235 & 55,233 & -2 & 100.0 \\
\hline leather & 67,437 & 21,990 & $-45,447$ & 32.6 \\
\hline wood-processing & 56,837 & 68,487 & 11,650 & 120.5 \\
\hline pulp and paper & 28,865 & 20,516 & $-8,349$ & 71.1 \\
\hline printing & 17,077 & 35,902 & 18,825 & 210.2 \\
\hline chemical & 118,971 & 101,884 & $-17,087$ & 85.6 \\
\hline glass making and building materials & 123,023 & 78,089 & $-44,934$ & 63.5 \\
\hline metallurgical and metalworking & 250,498 & 229,594 & $-20,904$ & 91.7 \\
\hline engineering & 593,573 & 239,104 & $-354,469$ & 40.3 \\
\hline electrotechnical & 152,072 & 149,584 & $-2,488$ & 98.4 \\
\hline other manuf. industries & 83,464 & 75,312 & $-8,152$ & 90.2 \\
\hline manufacturing industry & $1,847,434$ & $1,294,821$ & $-552,613$ & 70.1 \\
\hline industry, total & $2,114,882$ & $1,429,508$ & $-685,374$ & 67.6 \\
\hline economy, total & $5,236,908$ & $4,768,338$ & $-468,570$ & 91.1 \\
\hline
\end{tabular}

Source: CZSO (1990); Toušek, Tonev (2002) 
In the Czech Republic, the sector of agriculture lost 400,000 employees and industry lost close to 700,000 employees in the period 1989-1999, i.e. in the first decade of the economic transformation. In the manufacturing industry, the number of employee dropped by 550,000 and the remaining share of the labour force drop was related to the mining and quarrying and partly to power generation and distribution. However, this decrement did not affect all the branches of the manufacturing industry (see Table 2). In absolute terms, the greatest drop falls to the labour force in traditional Czech engineering; in relative terms, to the leather industry.

The drop in the labour force in industry stopped over the following years and as a result of the increasing direct foreign investments the employment rate in this economic sector even rose. The foreign investment inflow was conditioned by an incentive system adopted by the government of the Czech Republic in 1998. The incentives included subsidies for newly created jobs, subsidies for re-qualification courses, ten-year tax holidays and a possibility of acquiring cheap land in new business parks. The employment rate was on the rise until the first half of 2008. After that, the industrial production in the Czech Republic dropped as a result of the global economic crisis being accompanied by massive dismissals. As of the date of the latest census $\left(26^{\text {th }}\right.$ March, 2011), the manufacturing industry employed roughly the same number of people as at the end of 1999 (see Tab. 3).

Tab. 3. Labour force in manufacturing industry at the end of 1989 and 1999 and as of $26^{\text {th }}$ March 2011

\begin{tabular}{|l|r|r|r|c|}
\hline Branch of manufacturing industry & 1999 & 2011 & $\begin{array}{c}\text { difference } \\
2011-1999\end{array}$ & $\begin{array}{c}\text { change index } \\
2011 / 1999 * 100\end{array}$ \\
\hline food-processing & 146,551 & 131,090 & $-15,461$ & 89.5 \\
\hline textile & 72,575 & 40,118 & $-32,457$ & 55.3 \\
\hline clothing & 55,233 & 18,670 & $-36,563$ & 33.8 \\
\hline leather & 21,990 & 6,387 & $-15,603$ & 29.0 \\
\hline wood-processing & 68,487 & 40,242 & $-28,245$ & 58.8 \\
\hline pulp and paper & 20,516 & 15,753 & $-4,763$ & 76.8 \\
\hline printing & 35,902 & 25,519 & $-10,383$ & 71.1 \\
\hline chemical & 101,884 & 124,175 & 22,291 & 121.9 \\
\hline glass making and building materials & 78,089 & 53,867 & $-24,222$ & 69.0 \\
\hline metallurgical and metalworking & 229,594 & 224,564 & $-5,030$ & 97.8 \\
\hline engineering & 239,104 & 366,437 & 127,333 & 153.3 \\
\hline electrotechnical & 149,584 & 172,732 & 23,148 & 115.5 \\
\hline other manuf. industries & 75,312 & 72,772 & $-2,540$ & 96.6 \\
\hline manufacturing industry & $1,294,821$ & $1,292,326$ & $-2,495$ & 99.8 \\
\hline industry, total & $1,429,508$ & $1,412,756$ & $-16,752$ & 98.8 \\
\hline economy, total & $4,768,338$ & $5,040,366$ & 272,028 & 105.7 \\
\hline
\end{tabular}

Source: Toušek, Tonev (2002); CZSO (2012): Preliminary results of Census 2011 
While the number of people working in the sector of engineering, electrotechnical and chemical industries increased as a result of the foreign capital (plastic material production), the labour force dropped in other sectors. The rising number of employees in the aforesaid three sectors was linked to the car manufacturing industry boom in the Czech Republic. The biggest decline in employment rate over 1999-2011 was recorded by the leather manufacturing and clothing industries. Sectors experiencing the biggest drop in employment rate also included the textile and wood-processing industries and glass making and construction material industries.

At the time of the crisis (mid-2008 until mid-2010), the number of people working in industry declined by roughly 200,000. In a number of industrial sectors, the number of employees dropped by more than a quarter over two years. This concerned the textile, clothing, and leather, glass making and building material industries, metallurgical industry, furniture making and PC industries. In the second half of 2010 and in 2011, the labour force in industry slightly increased. Considering the whole period after 1989 until the 2011 census, the individual branches of the manufacturing industry can be divided into four groups:

a) branches with a major decline in labour force (leather industry employing only $9.5 \%$ in 2011 compared to the number in 1989 ; textile industry $25.8 \%$; clothing $33.8 \%$ and glass making and building materials $43.8 \%$ ),

b) branches with a significant decline in labour force (pulp and paper industry $54.6 \%$; engineering $61.7 \%$ and wood processing $70.8 \%$ ),

c) branches with a slight decline in labour force (other branches of manufacturing industry including, in particular, furniture making $87.2 \%$; metallurgical and metal working industry $89.6 \%$ and food-processing industry $90.4 \%$ ),

d) branches with a rise in labour force (chemical industry $104.4 \%$; electrotechnical industry $113.6 \%$ and printing industry $149.4 \%$ ).

During 1989-2011, the size structure of business entities operating in the industrial sectors changed as well. While the employment rate in industry was mainly linked to large state-owned companies during the period of centrally controlled economy, only one company with more than 20,000 employees and other two separate companies with more than 5,000 employees currently operate in the manufacturing industry. However, the greatest changes occurred in the regional structure of the manufacturing industry. The closing down of the traditional industrial production and the commencement of the operation of newly developed industrial sites has resulted in diversified industrial production in the regions and districts of the Czech Republic. This is also confirmed by the calculations of specialisation indices for a reduced number of districts (districts of Prague-West and Prague-East were annexed to the capital, the districts of Pilsen-South and Pilsen-North were annexed to the city of Pilsen, the district of Brno-Province was annexed to the city of Brno, the district of Karviná to the city of Ostrava and the district of Jeseník with the smallest number of inhabitants was annexed to the district of Šumperk). In 1989, three were 62 reduced districts where the specialisation index of at least one branch of industry ${ }^{2}$ exceeded the value of 2.0, which means that the

${ }^{2}$ The original number of thirteen branches of the manufacturing industry was reduced to eight by combining the textile, clothing and leather manufacturing industries and by combining wood-processing, paper making, printing and other industries. 
proportion of industrial sector to total employment in the district was at least twice higher than the proportion of this branch of industry to the total employment in the Czech Republic. In 2011 (see Tab. 4), the number of such districts was only 29. Superiority was gained by districts with a diversified structure of the manufacturing industry (without the specialisation index of 2.0 and more in some branches of industry). The period of 1989-2011 can be characterised in regional terms as a period of transition from industrial branch specialisation towards industrial diversification.

Tab. 4. Number of "districts in the Czech Republic" according to the specific types of manufacturing industry specialisation in 1989, 1999 and 2011

\begin{tabular}{|l|c|c|c|}
\hline \multicolumn{1}{|c|}{ Types } & 1989 & 1999 & 2011 \\
\hline Food-processing & 1 & 3 & 0 \\
\hline Textile, clothing, leather & 13 & 9 & 1 \\
\hline Wood-processing, paper making, printing, other processing & 5 & 8 & 3 \\
\hline Chemical & 5 & 4 & 5 \\
\hline Glass making and building materials & 7 & 8 & 2 \\
\hline Metallurgical and metal working & 5 & 3 & 1 \\
\hline Engineering & 23 & 8 & 15 \\
\hline Electrotechnical & 3 & 3 & 2 \\
\hline Diversified & 8 & 24 & 41 \\
\hline Total & 70 & 70 & 70 \\
\hline
\end{tabular}

Source: CZSO (1990); Toušek, Tonev (2002); CZSO (2012): Preliminary results of Census 2011

Tab. 5. Employment in services in the EU-27 countries (\% in total employment)

\begin{tabular}{|c|l|c|c|l|c|}
\hline \multicolumn{2}{|c|}{ Year 2001 } & \multicolumn{3}{c|}{ Year 2011 } & $\%$ \\
\hline No. & Country & $\%$ & No. & Country & 85.7 \\
\hline 1 & Luxembourg & 77.0 & 1 & Luxembourg & 80.1 \\
\hline 2 & Netherlands & 75.3 & 2 & Netherlands & 79.6 \\
\hline 3 & United Kingdom & 73.9 & 3 & United Kingdom & \\
\hline$\cdot$ & & & $\cdot$ & & \\
\hline 17 & Hungary & 59.3 & $\cdot$ & & \\
\hline$\cdot$ & & & $\cdot$ & & 64.3 \\
\hline 21 & Slovakia & 56.7 & 20 & Hungary & \\
\hline$\cdot$ & & & $\cdot$ & & 59.5 \\
\hline 24 & Czech Republic & 54.4 & 24 & Slovakia & 58.4 \\
\hline 25 & Slovenia & 52.6 & $\mathbf{2 5}$ & Czech Republic & $\mathbf{5 6 . 9}$ \\
\hline 26 & Poland & 50.7 & 26 & Poland & 44.4 \\
\hline 27 & Romania & 33.1 & 27 & Romania & 70.0 \\
\hline & EU-27 & 63.6 & & EU-27 & \\
\hline
\end{tabular}

Source: EUROSTAT (2012): Labour Force Survey - Employment and Unemployment 
A common feature of the V4 country is not only a high employment rate in industries but also a relatively low employment rate in services to date (perhaps with the exception of Hungary). The trend of accelerated convergence of the V4 countries to advanced European economies in terms of employment in the branches of services taking place during the first decade of transformation was replaced by a much slighter increase at the beginning of this century, namely in Slovakia, and in the Czech Republic. Although the tertiary sector became the biggest employer even in the transition economies in the 1990's with respect to the production sector, the existing share of people employed in services staying below $60 \%$ is still relatively low. The share of the tertiary sector in the employment rate in the EU has exceeded $70 \%$ and in eight EU countries it is even above $75 \%$ of labour force employed in services.

\section{Changes in the EduCATional STRUCture OF THE EMPLOYED}

The educational structure of the labour force in the Czech Republic has also been undergoing significant changes over recent years. Until 1970, the most numerous group declared primary school as their received level of education. These people formed two-fifths of economically active people. The number of people completing secondary education without the GCE was somewhat lower, and the share of people with university education was the lowest (4.8\%). Ten years later, the most numerous group was formed by people with secondary education without the GCE (see Tab. 6). The importance of this group for the labour force in the Czech Republic was on the rise until 1991. The 1991 census revealed that the share of people with secondary education without the GCE totalled $43.6 \%$ and these people formed also the most numerous group of economically active people in 2001 . This was the first year when the census showed a higher number of economically active people with university education than people completing primary education only. In 2011, the most numerous group was formed by people with secondary education and with the GCE.

Tab. 6. Economically active population according to the level of education (\%)

\begin{tabular}{|c|c|c|c|c|}
\hline Census & $\begin{array}{c}\text { Basic, pre-primary } \\
\text { and without education }\end{array}$ & $\begin{array}{c}\text { Secondary education } \\
\text { without GCE }\end{array}$ & $\begin{array}{c}\text { Secondary education } \\
\text { with GCE }\end{array}$ & $\begin{array}{c}\text { Tertiary } \\
\text { education }\end{array}$ \\
\hline 1970 & 40.7 & 37.3 & 17.2 & 4.8 \\
\hline 1980 & 31.5 & 40.7 & 21.0 & 6.8 \\
\hline 1991 & 18.6 & 43.6 & 28.2 & 9.6 \\
\hline 2001 & 10.3 & 42.5 & 34.3 & 11.9 \\
\hline 2011 & 8.2 & 36.9 & 37.8 & 17.1 \\
\hline
\end{tabular}

Source: 1970, 1980, 1991, 2001 censuses+ Preliminary results of Census 2011

During the last census, the unemployed persons amounted to almost one tenth of economically active population. Table 7 shows the differing educational structure of the employed and unemployed. Amongst the employed people, only $6.6 \%$ have only received primary education or have no education, while this share is much higher with the unemployed 
$(23.1 \%)$. On the contrary, the number of persons with tertiary education is three times higher in the group of the employed than amongst the unemployed. As regards the unemployed, the largest group is still formed by people with secondary education without the GCE.

Tab. 7. The employed, unemployed and economically active population in 2011 (\%)

\begin{tabular}{|l|c|c|c|c|}
\hline & $\begin{array}{c}\text { Basic, pre-primary } \\
\text { and without education }\end{array}$ & $\begin{array}{c}\text { Secondary education } \\
\text { without GCE }\end{array}$ & $\begin{array}{c}\text { Secondary education } \\
\text { with GCE }\end{array}$ & $\begin{array}{c}\text { Tertiary } \\
\text { education }\end{array}$ \\
\hline employed & 6.6 & 36.3 & 38.8 & 18.3 \\
\hline unemployed & 23.1 & 42.7 & 27.9 & 6.3 \\
\hline $\begin{array}{l}\text { economically } \\
\text { active }\end{array}$ & 8.2 & 36.9 & 37.8 & 17.1 \\
\hline
\end{tabular}

Source: CZSO (2012): Preliminary results of Census 2011

The above-mentioned educational structure is also reflected in the specific unemployment rates. In 2011, similarly to 2001, the unemployment rate of people with the lowest education exceeded $25 \%$, which was by 2.2 percentage points higher than ten years ago. As shown in Tab. 8, all groups of people with the same level of education had a higher unemployment rate in 2011 compared to 2001. Generally speaking, the specific unemployment rate was decreasing with the rising level of education.

Tab. 8. Specific unemployment rates according to the highest received level of education (\%)

\begin{tabular}{|c|c|c|c|c|c|}
\hline Census & $\begin{array}{c}\text { Unemployment } \\
\text { rate }\end{array}$ & $\begin{array}{c}\text { Basic, pre- } \\
\text { primary and } \\
\text { without education }\end{array}$ & $\begin{array}{c}\text { Secondary } \\
\text { education } \\
\text { without GCE }\end{array}$ & $\begin{array}{c}\text { Secondary } \\
\text { education } \\
\text { with GCE }\end{array}$ & $\begin{array}{c}\text { Tertiary } \\
\text { education }\end{array}$ \\
\hline 1991 & 2.3 & 3.9 & 1.8 & 2.0 & 1.8 \\
\hline 2001 & 9.2 & 25.3 & 9.6 & 6.3 & 2.3 \\
\hline 2011 & 9.8 & 27.5 & 11.3 & 7.2 & 3.6 \\
\hline
\end{tabular}

Source: 1991, 2001 censuses + Preliminary results of Census 2011

According to Eurostat data on the educational structure of the unemployed inhabitants based on selected labour force surveys, the employed are only divided into three groups, representing inhabitants with complete or incomplete primary education (or, as the case may be, no education), inhabitants with secondary education and inhabitants with tertiary education. According to this source, the Czech Republic ranks amongst countries with the lowest share of people with tertiary education, i.e. 18.8\% in 2011. A lower share was only reported by Italy (17.2\%) and Romania (17.8\%). Other countries with the share below $20 \%$, include Portugal and Slovakia. If the Eurostat database is objective, Poland was the country with the highest increase in the number of employed university graduates in the period from 2001-2011 with the number of university graduates almost doubled (from 2 million to 4.5 million people). Given this number of employed university graduates, Poland (27.2\%) surpassed Hungary (23.7\%); nevertheless, the country still fails to reach the average values in the European Union (28.7\%). EU countries with the highest share of employed university graduates are Ireland (41.3\%), Luxemburg, Cyprus, Belgium, Finland, Great Britain, Lithuania and Estonia (35.8\%). 
In assessing the educational structure of the EU countries, one needs to bear in mind that the systems of schooling differ from one country to another. On the one hand, the Czech Republic ranks as one of the countries with the lowest share of employed people with tertiary education, but on the other hand, it is a country with the highest share of people with secondary education totalling $75.6 \%$ in 2011 . The share of the employed people with primary education totalled as little as $5.6 \%$, which is the second lowest value in the EU countries (Lithuania 5.5\%).

In the Czech Republic, there are relatively significant differences in the educational structure of the employed inhabitants at the regional, district and municipal levels. The last census data from 2011 indicate the highest share of university graduates in the capital of Prague. The city of Brno reached almost the same share. Given the Czech environment, a high share was also recorded in Olomouc, Hradec Králové and Zlín. Table 9 shows the standing of ten districts with the highest share. On the contrary, the number of university graduates is low in the regions of Pilsen, Karlovy Vary and Ústí. The share of university graduates was below $10 \%$ in the districts of Sokolov and Tachov in the west of Bohemia.

Tab. 9. Ten districts of the Czech Republic with the largest share of university graduates in 2011

\begin{tabular}{|c|l|c|c|l|c|}
\hline No. & \multicolumn{1}{|c|}{ District } & $\%$ & No. & \multicolumn{1}{c|}{ District } & $\%$ \\
\hline 1 & Prague & 32.4 & 6 & Ostrava-City & 21.7 \\
\hline 2 & Brno-City & 32.3 & 7 & Hradec Králové & 20.9 \\
\hline 3 & Prague-West & 27.7 & 8 & Olomouc & 20.7 \\
\hline 4 & Prague-East & 22.2 & 9 & České Budějovice & 20.6 \\
\hline 5 & Pilsen-City & 22.2 & 10 & Zlín & 18.9 \\
\hline
\end{tabular}

Source: CZSO (2012): Preliminary results of Census 2011

The share of university graduates in the total employment increased in the period from 2001-2011 by less than 6 percentage points, which was lower than in the rest of the EU, where the share of university graduates rose from $21.4 \%$ to $28.7 \%$. However, in the Czech Republic, there were districts with the rate of increase outpacing the growth in the whole EU. This mainly concerned the districts of Prague-West, with the number of university graduates rising from $14.9 \%$ to $27.7 \%$, followed by the districts of Prague-East, Capital of Prague and Brno-Province. On the one hand, the proportion of university graduates to the labour force increased in the hinterlands of large cities and also in the cities themselves. On the other hand, there was a very slight increase in the number of university graduates in the peripheral districts such as Tachov, Sokolov, Cheb and Domažlice (all located in the west of Bohemia). Regional differences between economically prospering and lagging areas were increasing.

In the analysed period from 2001-2011, the situation of regional labour markets became more dependant on the level of education of the local working population. At the beginning of this century, regional differences in the unemployment rate depended mainly on the economic structure of the districts developed during the period of centrally controlled economy. The highest level of unemployment was reported by structurally impacted areas, such as the region of Ostrava and the north of Bohemia and economically underdeveloped rural regions 
relying on agricultural production. The above facts are also confirmed by the Pearson correlation coefficient between the unemployment rate and the proportion of university graduates to the employed, which totalled as little as -0.13 in the group of 77 districts of the Czech Republic in 2001. Ten years later, the correlation coefficient was -0.41 .

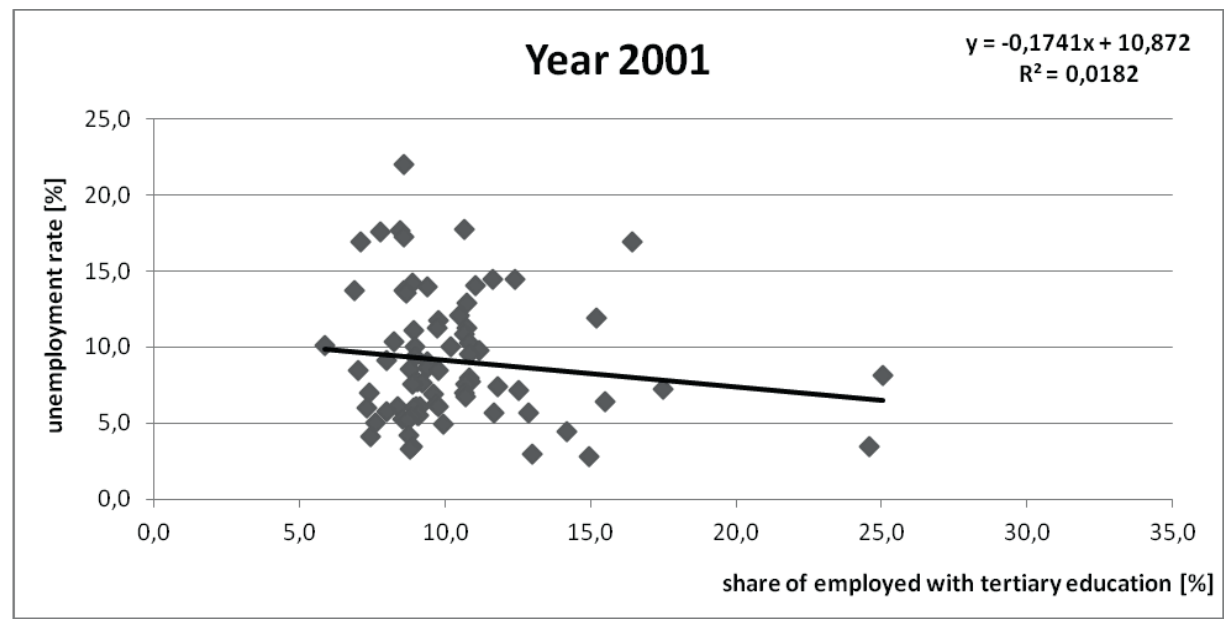

Fig. 1. Relationship between the unemployment rate (\%) and the share of employed persons with tertiary education employed in the districts of the Czech Republic in 2001

Source: MoLSA (Ministry of Labour and Social Affairs) (2001): Integrated portal of the MoLSA; CZSO (2003): Census as of 1st March 2001- inhabitants, flats, houses and households

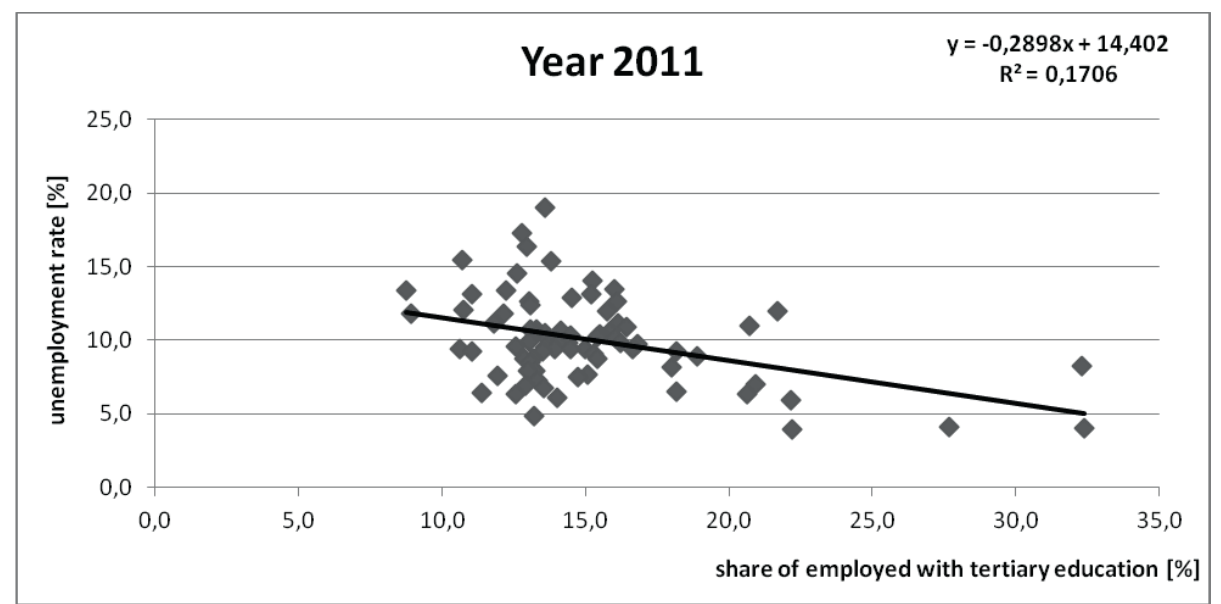

Fig. 2. Relationship between the unemployment rate (\%) and the share of employed people with tertiary education employed in the districts of the Czech Republic in 2011 
People with tertiary education are relatively few in the production sectors of the economy (see Tab. 10). In 2011, the share of university graduates in the Czech Republic working in the sector of agriculture, forestry and fisheries was higher than in a number of EU countries compared to industry and construction. This was also the case ten years ago. Currently, in the tertiary sector, every fourth person in the Czech Republic has received tertiary education. The high share of university graduates can be seen in the branch of education $(48.9 \%)$, services for businesses (real estate, renting and business activities), financial intermediation and public administration. On the contrary, very few people with tertiary education were employed in the branch of accommodation and restaurants (4.4\%).

Tab. 10. Persons with tertiary education according to the sectors in 2001 and 2011

\begin{tabular}{|l|r|r|r|r|}
\hline \multirow{2}{*}{\multicolumn{1}{|c|}{ Branches (sectors) }} & \multicolumn{2}{c|}{2001} & \multicolumn{2}{c|}{2011} \\
\cline { 2 - 5 } & number & $\%$ & number & $\%$ \\
\hline Primary sector & 17,869 & 7.2 & 15,168 & 10.9 \\
\hline agriculture and hunting & 14,197 & 7.2 & 11,628 & 10.6 \\
\hline forestry and fishing & 3,672 & 7.3 & 3,540 & 11.9 \\
\hline Secondary sector & 143,512 & 6.7 & 160,193 & 9.7 \\
\hline industry & 99,859 & 6.1 & 122,601 & 9.4 \\
\hline construction & 43,652 & 8.9 & 37,592 & 10.7 \\
\hline Tertiary sector & 462,230 & 16.2 & 662,863 & 24.0 \\
\hline trade & 38,809 & 6.5 & 49,907 & 9.6 \\
\hline hotels and restaurants & 3,816 & 1.8 & 7,079 & 4.4 \\
\hline transport, storage and communication & 21,525 & 5.7 & 40,602 & 11.3 \\
\hline financial intermediation & 26,778 & 22.8 & 39,695 & 31.4 \\
\hline real estate, renting and business activities & 79,340 & 26.8 & 139,677 & 38.4 \\
\hline public administration & 68,590 & 19.7 & 92,393 & 30.6 \\
\hline education & 129,266 & 43.0 & 151,476 & 48.9 \\
\hline health and social work & 62,312 & 19.8 & 85,511 & 25.4 \\
\hline other community, social and personal services & 31,793 & 11.2 & 56,523 & 19.8 \\
\hline TOTAL & 17,869 & 7.2 & 15,168 & 18.4 \\
\hline
\end{tabular}

Source: CZSO (2003): 2001 census; CZSO (2012): Preliminary results of Census 2011

In 2011, the share of persons with tertiary education reached $9.0 \%$ both in mining and quarrying and, in manufacturing. A somewhat higher share of university graduates worked in the sector of electricity, gas and water supply (14.9\%). As regards manufacturing, more than a $10 \%$ share of people with tertiary education worked in the chemical industry $(14.3 \%)$ and in electrotechnical (12.0\%) industries. On the contrary, in three branches of the manufacturing industry, the proportion of university graduates to the employed was less than $5 \%$. These were the sectors of wood-processing (4.5\%), clothing (4.7\%) and leather manufacturing $(4.7 \%)$. 


\section{CONCLUSION}

At the end of the 1980s, the Czech Republic (along with Slovakia) strongly differed in terms of the sector and educational structure of labour force from the other European countries. The Czech Republic was distinguished by a high employment rate in the secondary sector of the economy, particularly the manufacturing industries, while the tertiary sector was undersized, similarly to the other post-socialist countries. The share of people with complete or incomplete primary education or without any education was the lowest amongst all European countries and the share of persons with secondary education was the highest. Given the proportion of university graduates to the labour force in the Czech Republic, the country ranked with countries with a low representation of this group of inhabitants.

After 1989, during the transformation period, the sector-related and educational structure of inhabitants in the Czech Republic started approaching the developed market economies. Changes in the sector-related structure of the employed population were much more rapid. More than half a million people left the production sectors of the economy before the end of 1992. At the end of that year, the tertiary sector became the leading employer. Three years later, services employed a higher share of labour force than the primary and secondary sectors together. Nevertheless, the share of people working in services in the Czech Republic is still low in comparison with the developed countries. Major sector-related changes occurred also in the manufacturing industry. Leather manufacturing presently employs one tenths of people compared to the state at the end of 1989, the printing industry employs more people than in 1989 , i.e. by approximately $50 \%$ more. Recently, higher-added-value production has been increasing with the growing number of employees. This is also reflected in the educational structure of the employed population.

In the 1990s, the group of persons with secondary education with the GCE was the fastest growing group. After 2000, the fastest growing group was that of people with tertiary education. This fact was reflected by the increasing number of university students and schools. During the 1990s, the number of students rose from 100,000 to 200,000 and in the academic year 2011/2012, the Czech Republic recorded almost 400,000 university students. However, the rise in the number of university graduates does not necessarily have a positive impact on the economic results of the country. A similar analysis of the results of tests conducted in fifteen OECD countries and recently also in some other countries indicates that the education standard of pupils leaving primary schools in the Czech Republic is declining in contrast with Hungary, and, in particular, Poland (PISA, 2000, 2009). Thus, it may be assumed that the level of knowledge of the secondary and university students is also declining in a similar fashion and the effect of the higher educational structure for the national economy is much lower. 


\section{References}

Barta, G. (2005). The Role of Foreign Direct Investment in the Spatial Restructuring of Hungarian Industry. In: G. Barta, É.G. Fekete, I. Kukorelli Szörényiné, J. Timár (eds.). Hungarian Spaces and Places: Patterns of Transition, Pécs: Centre for Regional Studies, 143-160.

Barta, G., Czirfusz, M., Kukely, G. (2008). Re-industrialisation in the World and in Hungary. European Spatial Research and Policy, 15 (2), 5-26.

Domański, B. (2011). Foreign Capital and the Development of Polish Regions. Czasopismo Geograficzne, 82 (1-2), 173-187.

Fišer, P., Toušek, V., Janota, M. (2008). Changes in Employment Structure in the Czech Republic Influenced by the Transformation of Economy. In: D. Ilnicki, K. Janc, (eds.), Przekształcenia regionalnych struktur funkcjonalno-przestrzennych: Europa bez granic - nowe wyzwania. Wroclaw: University of Wroclaw, 107-114.

Gierańczyk, W., Rachwał, T. (2012). Structural Changes in the Industry of Poland against the Background of Eastern European Union States. Quaestiones Geographicae, 31 (2), 83-93.

Kulla, M. (2005). Transformácia priemyslu Bratislavy po roku 1989, dissertation, Bratislava: Komenský University in Bratislava.

Kunc, J. (2005). Transformace českého průmyslu po roce 1989 - vliv přimých zahraničních investic: regionálně geografická analýza s důrazem na Jihomoravský kraj a kraj Vysočina, dissertation. Brno: Masaryk University.

Pavlínek, P. (2004). Regional Development Implications of Foreign Direct Investment in Central Europe. European Urban and Regional Studies, 11 (1), 47-70.

Popjaková, D. (2008). Globálna verzus postsocialistická transformácia priemyslu (na príklade Slovenska), Acta geographica Universitatis Comenianae, 51, 3-25.

Stryjakiewicz, T. (2009). The Old and the New in the Geographical Pattern of the Polish Transition. Acta Universitatis Palackianae Olomucensis. Facultas Rerum Naturalium - Geographica, $40(1), 5-24$.

Šerý, O. (2012). Zaměstnanost v České republice: hodnocení změn odvětvové a vzdělanostní struktury (s využitím predběžných výsledků sčitání lidu 2011), rigorous thesis. Brno: Masaryk University.

Toušek, V., Tonev, P., (2002). Typologie okresů České republiky (podle struktury zaměstnaných s důrazem na odvětví zpracovatelského průmyslu). In: Balej, M. (ed.), XX. jubilejní sjezd ČGS „Evropská integrace - česká společnost a krajina“. Sborník tematického okruhu REG Regionální rozvoj / regionalizace. Ústí nad Labem: Univerzita J.E. Purkyně, 67-77.

Vančura, M. (2006). Vliv př́mých zahraničních investic na rozvoj regionů v České republice. In: Klímová, V. (ed.), Sborník referátů z IX. mezinárodního kolokvia o regionálních védách. Brno: Masarykova univerzita, Ekonomicko-správní fakulta, Katedra regionální ekonomie a správy, $233-239$.

Ženka, J. (2008). Riziko delokalizace zpracovatelského průmyslu Česka: regionální aspekty. Geografie (Sborník ČGS), 113 (1), 1-19.

Ženka, J. (2009). Delokalizace zpracovatelského průmyslu ČR (komponentní analýza), Politická ekonomie, 57 (1), 79-93.

\section{Data sources}

CZSO (Czech Statistical Office) (1990). Pracovníci a mzdové fondy socialistického sektoru národního hospodářství v krajich a okresech podle odvětvi národního hospodářství v ČSR za rok 1989. 1. vyd., ČSÚ, Praha, 193 pp. 
CZSO (Czech Statistical Office) (2003). Census as of 1st March 2001-inhabitants, flats, houses and households. ČZSO, Praha (all districts of the Czech Republic)

CZSO (Czech Statistical Office) (2012). Preliminary results of Census 2011 - population by economic activity and branch of economic activity + population by branch of economic activity and educational attainment [database]

EUROSTAT (2012). Employment and unemployment (Labour Force Survey). [online], Eurostat, Luxembourg, (http://epp.eurostat.ec.europa.eu/portal/page/portal/statistics/search_database) (accessed 01.09.2012).

MoLSA (Ministry of Labour and Social Affairs of the Czech Republic) (2001-2011). Integrated portal MoLSA - Employment, Unemployment Statisticts (http://portal.mpsv.cz/ sz/stat/nz/mes) (accessed 29.08.2012).

Ondřej Šerý, RNDr., Masaryk University, Faculty of Science, Department of Geography.

Ondřej Šerý $(* 1985)$ is a Ph.D. candidate in Regional Geography and Regional Development at Masaryk University in Brno. He focuses on the geography of industry (specifically the transformation of Central Europe), labour market and regional development.

Václav Toušek, CSc. doc. RNDr., Palacký University in Olomouc, Faculty of Science, Department of Geography.

Václav Toušek $\left({ }^{* 1949)}\right.$ is an associate professor at Palacký University in Olomouc and Masaryk University in Brno. He deals with economic geography, especially the regional geography, the geography of industry and the issues of labour market.

adres/address: Masaryk University, Faculty of Science,

Department of Geography, Kotlářská 2,

61137 Brno, Czech Republic (Ondřej Šerý)

e-mail: ondrej.sery@mail.muni.cz (Ondřej Šerý),vaclav.tousek@upol.cz (Václav Toušek) 